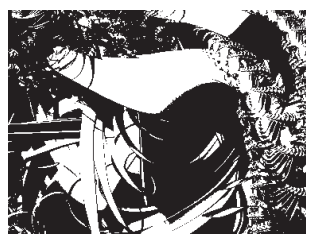

doi:10.5559/di.20.2.05

\title{
FORZA ITALIA: JEDNA TALIJANSKA PRIČA
}

Mirjana KASAPOVIĆ

Fakultet političkih znanosti, Zagreb

UDK: 329.051.055(450)"199/200" 32-051 Berlusconi, $\mathrm{S}$.

Izvorni znanstveni rad

Primlieno: 10. 7. 2009.

Otkako se pojavila na početku 1990-ih, Forza Italia izazivala je brojne nedoumice i prijepore među analitičarima talijanske politike i istraživačima političkih stranaka. O kakvoj je političkoj pojavi riječ? Ako je posrijedi bila stranka, je li se uklapala u kartelski, personalistički ili prezidencijalistički tip suvremenih europskih političkih stranaka? Ili je posrijedi bila još jedna "talijanska anomalija", koja se ne može teorijski poopćiti i kategorizirati? Pokazalo se da je Forza Italia bila talijanski izraz opće kartelizacije i prezidencijalizacije suvremene politike, koja je zahvatila tri velike političke arene: izbore, političke stranke $\mathrm{i}$ izvršnu vlast. $U$ tekstu se razmatraju način njezina nastanka, organizacijski ustroj, ideološki profil i obrasci političkoga dielovanja u te tri arene. Zaključuje se da je na munjevit politički uspon Forza Italia presudno utjecalo nekoliko kontekstualnih čimbenika: potpuno urušavanje starih talijanskih političkih stranaka i stranačkoga sustava, koje je nagnalo birače da napuste svoje tradicionalne katoličke i sekularne tabore, podrijetlo stranke iz medijskoga koncerna, što joi je omogućilo da potpuno medijski kolonijalizira politiku, nezaziranje Berlusconija od sklapanja političkih saveza s prołusustavskim strankama, njegov osobni politički stil koji se pretočio u neformalna pravila djelovanja u političkim institucijama te neprezanje od kriminogenih metoda dielovanja.

Ključne riječi: Forza Italia, prezidencijalizacija politike, predsjednička stranka, kartelska stranka, berluskonizam

$\triangle$ Mirjana Kasapović, Fakultet političkih znanosti, Lepušićeva 6, 10000 Zagreb, Hrvatska.

E-mail: mkasapovic@fpzg.hr

\section{UVOD}

Kad bi se doista moglo govoriti o tome da je 1990-ih godina završeno razdoblje Prve Republike i da su Talijani kročili u eru Druge Republike, ${ }^{1}$ to bi ponajprije bio rezultat potpunog uru- 
DRUŠ. ISTRAŽ. ZAGREB GOD. 20 (2011) BR. $2(112)$

STR. 379-399

KASAPOVIĆ, $M$ : FORZA ITALIA.. šavanja staroga i oblikovanja novoga stranačkog sustava. A u novom sustavu središnje je mjesto zauzela Forza Italia, nova politička stranka i umnogome nova politička pojava uopće. Ona je izazvala toliko nedoumica i oprečnih stajališta kao rijetko koji noviji fenomen u suvremenoj talijanskoj i europskoj politici. O kakvoj je političkoj stranci riječ? Predsjedničkoj stranci, koja se uklapala u opće tendencije prezidencijalizacije politike u svim zapadnim demokracijama? O tradicionalnoj karizmatičnoj ili suvremenoj personalističkoj stranci? O kartelskoj stranci, jednome od evolucijskih tipova političkih stranaka, obrisi kojega su se nazirali već 1970 -ih godina?

Mnogo odgovora na ta pitanja upućuje na to s kakvim su se sve dvojbama suočili analitičari talijanske politike i istraživači političkih stranaka uopće. Konvencionalne teorijske kategorije - elitna, kadrovska, narodna, karizmatična, personalistička, izborna, patrimonijalna stranka - nisu bile dostatne da obuhvate sve osobitosti nove pojave. Stoga se posegnulo za nekonvencionalnim opisima koji bi točnije izrazili njezinu bit: instant-stranka, videostranka, tvrtka-stranka, poslovna stranka, korporacijska stranka, medijska stranka, odborska stran$\mathrm{ka}$, virtualna stranka, retortna stranka, plastična stranka, $c y$ ber-formacija, komercijalni proizvod, firerska stranka, pokretaška stranka, protustranačka stranka, Forza Silvio, Forza Berlusconi itd.

Ugledni talijanski politolog Angelo Panebianco vidio je $u$ stranci Forza Italia vjesnika kraja ere masovnih i pučkih stranaka i početka razdoblja predsjedničkih stranaka, koje su organizacijski ustrojene kao "superizborni odbor" kako bi pobijedile na izborima. On je u njoj vidio empirijsku potvrdu svojih postavki o tome da se duboko zašlo u razdoblje "profesionalnih izbornih stranaka", koje su uvelike odbacile ideološku, političku i organizacijsku prtljagu starih masovnih i pučkih stranaka (Panebianco, 1988.). Drugi ugledni talijanski politolog, Leonardo Morlino (1996.), ustvrdio je da je Forza Italia tipična kartelska stranka ili tvrtka-stranka, to jest svojevrstan politički kartel, ustrojen i vođen prema pravilima privredne korporacije. Ta su dvojica politologa bila najbliža točnom određenju što je to Forza Italia, koja je u sebi obuhvatila elemente prezidencijalističke i kartelske stranke, ali s mnogo posebnosti koje su je učinile krajnje intrigantnom pojavom u suvremenoj politici.

Nastanak predsjedničkih stranaka smatra se elementom prezidencijalizacije politike u suvremenim demokracijama. Pod njom se misli na političke procese koje obilježuju sve veća usredotočenost na političke vođe $\mathrm{u}$ izbornim procesima te povećanje izvora njihove moći i samostalnosti u političkim strankama i izvršnoj vlasti. Posrijedi je strukturno i kontekstualno uvjetovan proces koji ima više uzroka (Poguntke i Webb, 2005., 13-17). 
DRUŠ. ISTRAŽ. ZAGREB GOD. 20 (2011), BR. 2 (112)

STR. 379-399

KASAPOVIĆ, $M$ FORZA ITALIA..
Prvi je uzrok internacionalizacija politike, koja iziskuje zajedničko djelovanje i suradnju nacionalnih vođa u rješavanju međunarodnih političkih i društvenih problema. Nacionalne vlade prisiljene su surađivati u oblikovanju politikâ borbe protiv terorizma, rješavanja etničkih sukoba diljem svijeta, imigracijske politike, zaštite okoliša, kontrole globalnih financijskih tržišta i transnacionalnih ulaganja itd. Kako se o tim politikama razgovara i pregovara na međuvladinim razinama, šefovi vlada postaju ključni akteri politike. Vlade i parlamenti samo ratificiraju odluke što su ih donijeli premijeri ili predsjednici država. Drugi je uzrok dugoročan "rast države", koji se izražava u povećanju birokratske kompleksnosti i organizacijske specijalizacije ili sve veće institucionalne diferencijacije - umnožavanja tipova organizacija, posredovanjem kojih vlasti djeluju, kao i institucionalne specijalizacije - umnožavanja istoga tipa organizacija. To uzrokuje centralizaciju moći u izvršnoj vlasti, koja preuzima posao i odgovornost za usklađivanje "institucionalnih fragmenata", ali i potkopava kolektivnu odgovornost vlade. Naime, trend sektorskog oblikovanja javnih politika iziskuje dvostrane kontakte između mjerodavnih ministarstava i šefa izvršne vlasti. Treći uzrok treba tražiti u promjeni strukture masovnih medija, poglavito u prevlasti elektroničkih medija, koji su korjenito promijenili prirodu masovnoga komuniciranja. Televizija je prirodno usredotočena na ličnosti, a ne na sadržaje, te reducira kompleksnost političkih poruka i prilagođuje njihov sadržaj i smisao svojim pravilima. Stoga se politički akteri prilagođuju zahtjevima i standardima medija, a mediji, shodno tomu, "kolonijaliziraju" politiku. Četvrti je uzrok u eroziji politike koja se zasnivala na tradicionalnim društvenim rascjepima. Desetljećima se empirijski dokumentira slabljenje veza između političkih stranaka i društvenih klasa, slojeva ili skupina na koje se oslanjanju, čije interese, vrijednosti i identitete politički artikuliraju i predstavljaju te iz njih regrutiraju svoje birače. To je utjecalo na mijenjanje ideološkoga profila i organizacijskih obrazaca modernih političkih stranaka. Opća kartelizacija politike izrazila se i u zamjeni masovnih i pučkih stranaka kartelskim strankama, koje se umnogome organiziraju i djeluju prema obrascima koji su preuzeti iz privrednih korporacija. Kartelske stranke interpretiraju se kao proizvod duboke promjene odnosa između društva i države te između države i političkih stranaka. Tradicionalni jaz između društva i države, u koji su bile smještene moderne masovne stranke kao akteri koji su ga trebali organizacijski premošćivati, zamijenila je posvemašnja isprepletenost suvremenoga društva i države, koja je uvelike zatvorila stari jaz te tako "ostavila" stranke u obje sfere života. I dok su stare stranke djelovale kao agenti društva u državi, nove djeluju istodobno i kao agenti države u društvu. Učvrš- 
DRUŠ. ISTRAŽ. ZAGREB GOD. 20 (2011) BR. 2 (112),

STR. 379-399

KASAPOVIĆ, M.: FORZA ITALIA.. ćuje se simbioza između države i političkih stranaka, koja se izražava i u ekspanziji javnoga, odnosno proračunskoga, financiranja stranaka. Kartelske stranke djeluju kao "prodavači robe" na političkom tržištu, pa se strukturiraju i organiziraju kao suvremeni tržišni takmaci. Kako bi u nesmiljenim uvjetima tržišne političke utakmice postigle što bolje rezultate osvojile što više glasova i mandata te tako stekle što veći udio $\mathrm{u}$ vlasti - one se ustrojavaju i djeluju kao profesionalizirane i centralizirane organizacije $\mathrm{u}$ kojima je glavni akter stranačko vodstvo, dok je članstvo posve marginalizirano, atomizirano i, kad je to potrebno, kontekstualno instrumentalizirano. ${ }^{2}$

Općem trendu prezidencijalizacije politike nije umaknula ni Italija. Štoviše, ona je jedan od zanimljivijih primjera prezidencijalizacije "čiste" parlamentarne demokracije. Italija je dugo slovila kao primjer "integralnoga parlamentarizma", dakle političkoga sustava u kojemu parlament dominira nad vladom (Furlong, 2006., 185). No u zadnjih dvadesetak godina ona se pretvorila $\mathrm{u}$ "idealan tip prezidencijalizacije političkoga sustava" (Calise, 2005., 88). Prezidencijalizacija se zbiva u tri središnje arene demokratske politike: u izborima, političkim strankama i izvršnoj vlasti. U nastavku se opisuju procesi prezidencijalizacije $\mathrm{u}$ sve tri političke arene $\mathrm{u}$ Italiji na primjeru Forza Italia. Želi se ustanoviti je li se ona uklapala u obrazac prezidencijalizirane stranke. Ako se pokaže da je bilo tako, ne treba je promatrati kao odstupajući slučaj, kao "anomaliju" u talijanskoj i europskoj politici, pa ni kao oblik političke patologije koji u sebi sažimlje manipulativne i kriminogene elemente nespojive s demokratskom politikom.

\section{PREZIDENCIJALIZACIJA IZBORA I FORZA ITALIA}

Prezidencijalizacija izbora zbiva se $u$ obliku jačanja uloge političkih vođa na račun političkih stranaka u izbornim kampanjama. Izražava se u stilu izbornih kampanja, usredotočenosti medija na ličnosti umjesto na političke programe te u izraženome kandidatski usmjerenom glasovanju birača. U starijim izbornim studijama taj se fenomen nazivao personalizacijom izbora (Kasapović, 2004.), dok je u novijim studijama uklopljen u tematski šire i analitički zahtjevnije rasprave o prezidencijalizaciji politike. Personalizacija i prezidencijalizacija izbora nisu potpuno istovjetni pojmovi: dok se pod prvom misli na primarnu usmjerenost birača u izborima na pojedine kandidate umjesto na stranke i programe, pod drugom se razumijeva poglavita usmjerenost birača samo na političke vođe kao glavne kandidate. Prilično se uvriježilo mišljenje da je prezidencijalizacija izbora glavni uzrok prezidencijalizacije politike (Poguntke i Webb, 2005., 17). No to nije tako neprijeporno kako se možda čini. 
DRUŠ. ISTRAŽ. ZAGREB GOD. 20 (2011), BR. 2 (112)

STR. 379-399

KASAPOVIĆ, $M$ FORZA ITALIA..
U prezidencijalizaciji izbora u Italiji presudnu su ulogu imali Forza Italia i njezin čelnik Silvio Berlusconi. ${ }^{3}$ Oni su uspjeli potisnuti u drugi plan ideološko-političke i socijalno-kulturne rascjepe u biračkom tijelu te suzbiti stranačko i programsko opredjeljenje birača nauštrb opredjeljenja za političke vođe. Berlusconi je u tom pogledu bio posve otvoren: "U izbornoj borbi nećemo raspravljati o programima, jer to ne donosi glasove" (nav. u: Grasmück, 2005., 243). Program zamjenjuje "san", demagoški politički diskurs ustupa mjesto jednostavnome pučkom govoru, a riječi zamjenjuju simboli. Sve su izborne kampanje stranke Forza Italia bile potpuno usredotočene na jednoga kandidata. Izbori su se hotimice nastojali pretvoriti u plebiscit o jednome kandidatu. Na izbornim plakatima nalazio se samo lik Silvija Berlusconija. Uoči izbora 2001. svi kandidati desnoga centra dobili su izborni kovčežić u kojemu su se nalazili brošura Silvio Berlusconi: Una storia italiana, $\mathrm{u}$ kojoj je opisan Berlusconijev život, videosnimke njegovih govora te poseban naputak kandidatima o tome kako će biračima opisati Berlusconija. ${ }^{4}$ Sam je Berlusconi vodio kampanju kao kandidat za premijera te $\mathrm{u}$ izborima gotovo ništa drugo nije bilo važno osim njegova izbora na to mjesto.

\section{PREZIDENCIJALIZACIJA STRANAKA I FORZA ITALIA}

Unatoč proširenu mišljenju da prezidencijalizacija politike izvire iz izbora, razložno se može tvrditi da su njezini zameci u političkim strankama. Prije no što prezidencijaliziraju izbore, pojedinci moraju "monarhijski" ovladati postojećim strankama, poput Blaira u Velikoj Britaniji, ili osnovati potpuno nove stranke, poput Berlusconija u Italiji. Prezidencijalizacija postojećih stranaka očituje se u snažnom pomicanju težišta moći u korist vođa, a novih stranaka u njihovu početnom ustrojstvu kao privatnih, krajnje personaliziranih organizacija. Vođe postaju sve samostalniji $u$ odnosu prema "dominantnim koalicijama moći unutar stranaka" (Poguntke i Webb, 2005., 9, v. i Ansell i Fish, 1999.; Samuels, 2002.). Prvaci stranačkih frakcija i stranački aktivisti gube važnost u izboru vođa stranaka. Svojevrstan je demokratski paradoks da su stranački predizbori - izvorno zamišljeni kao demokratski postupak selekcije stranačkih kandidata za opće izbore, a kasnije i kao postupak izravnog izbora stranačkih vođa, koji su trebali spriječiti ili makar ublažiti oligarhizaciju političkih stranaka - pridonijeli osamostaljivanju vođa od članova i aktivista stranaka i povećanju njihove moći izvedene iz legitimnosti stečene izravnim izborima. Kandidat koji pobijedi na općim unutarstranačkim izborima ne iskorištava to samo kao "plebiscitarno pravo" da predstavlja stranku u izborima nego i da je gotovo potpuno supstituira. U skladu s tim, u političkoj komunikaciji u izbori- 
DRUŠ. ISTRAŽ. ZAGREB GOD. 20 (2011) BR. 2 (112),

STR. 379-399

KASAPOVIĆ, M.: FORZA ITALIA.. ma on se izravno obraća biračima, preskačući stranačke oblike posredovanja između sebe i biračkoga tijela.

Osim institucionalizacije izravnih unutarstranačkih izbora vođe stranke, prezidencijalizacija stranaka očituje se i u mijenjanju pravila o ustroju i organizaciji stranke kako bi vođa dobio veću formalnu moć, davanju veće mogućnosti vođi da programe oblikuje neovisno o stranci, povećanju osoblja i novca namijenjenih uredu vođe stranke, primjeni prebiscitarnih obrazaca političke komunikacije i mobilizacije, uvođenju personaliziranoga mandata $\mathrm{u}$ tom smislu da vodeći kandidati za vođe stranaka nisu stranački seniori ili "stranački baruni".

\section{Način nastanka i organizacijski razvoj Forza Italia}

Rijetko je koja suvremena stranka nastala kao prototipska prezidencijalistička i kartelska stranka kao Forza Italia. Osnovao ju je i financirao jedan čovjek kao organizacijsko sredstvo vlastita političkog uspona. Formirana je kao tajni, gotovo urotnički, projekt Berlusconija i nekolicine vodećih menadžera Pubitalije, reklamne agencije koju je osnovao 1979. i koja je postala jezgra njegova koncerna Fininvest. Otpočetka je zamišljena i vođena kao prvorazredan medijski projekt zasnovan na sustavnim istraživanjima političkoga tržišta, kako bi se ponuda stranke prilagodila potrebama i željama birača.

U organizacijskom razvoju stranke neki autori raspoznaju dvije (Hornig, 2007.), a neki tri faze (Grasmück, 2005.). Podjela na tri faze čini se uvjerljivijom zato što su se organizacijska struktura i dinamika mijenjale ovisno o političkom položaju stranke, odnosno o tome je li bila u opoziciji i borila se za vlast ili je bila na vlasti i borila se da ne ode u opoziciju.

U prvoj fazi od 1994. do 1996. Forza Italia se razvijala kao partito leggero, kao amerikanizirani "izborni odbor", koji se svjesno odrekao izgradnje čvrstih organizacijskih struktura. Prvi vidljivi organizacijski zameci bili su klubovi Forza Italia, osnovani prema uzoru na fan-klubove nogometnoga kluba Milan, kojima su izravno upravljali menadžeri Fininvesta što ih je imenovao Berlusconi. Stranka se pojavila na političkoj pozornici u siječnju 1994., tri dana nakon raspuštanja parlamenta, pod nazivom Politički pokret Forza Italia, koji je vodio Predsjednički odbor na čelu s Berlusconijem. Vodstvo stranke inzistiralo je na tome da Forza Italia nije stranka nego politički pokret. O masovnome političkom pokretu u pravom smislu riječi nije, pak, bilo ni govora, jer u trenutku pojave nije imala masovno članstvo, nije prakticirala stalnu političku mobilizaciju nego vremenski ograničenu i ciljanu izbornu mobilizaciju, a imala je i jasno podijeljene uloge i uspostavljene hijerahijske odnose kakvi nisu svojstveni pokretu. Forza Italia otpočetka je pokazivala obilježja stranke, makar $u$ rudimentarnim oblicima. No 
DRUŠ. ISTRAŽ. ZAGREB GOD. 20 (2011), BR. 2 (112)

STR. 379-399

KASAPOVIĆ, $M$ FORZA ITALIA.. na nazivu pokret nije se slučajno ustrajalo. Nakon traumatičnih iskustava s partitokracijom i sa slomom starih političkih stranaka, među Talijanima su se proširili snažni protustranački ressentimenti, pa su mnogi bili alergični i na spomen riječi stranka. ${ }^{5}$ Novu je političku tvorevinu stoga i nominalno trebalo odvojiti od stranaka i tako pridobiti simpatije birača. Nadalje, naziv pokret sugerirao je da nije posrijedi čvrsto strukturirana, hijerarhizirana i disciplinirana organizacija koja djeluje sporo i tromo te ne reagira brzo i pravodobno na političke i društvene izazove s kojima se zemlja suočavala. On je trebao poslati poruku građanima kako je riječ o fleksibilnoj i pragmatičnoj organizaciji koja brzo donosi odluke i rješava probleme. Pokret je imao predsjednika, predsjednički odbor, delegatsku skupštinu, lokalne klupske organizacije i statut, ali nije imao stranački aparat i aktivno stranačko članstvo. Statut je zapravo bio mrtvo slovo na papiru. Prvi stranački kongres održan je četiri godine nakon osnutka stranke. Predsjednički odbor zapravo je bio savjetodavno tijelo koje je imalo mnogo manji utjecaj od neformalnoga unutarnjeg kruga osoba iz Berlusconijevih tvrtki koje su mu bile osobno bliske i odane. Pokret je bio krajnje centralistički i hijerahijski ustrojen, a sva njegova tijela bila su izravno podređena Berlusconiju, koji je osobno imenovao članove Predsjedničkog odbora i regionalne koordinatore. U prvoj fazi stranka je djelovala kao izborni odbor, kao stroj za izbornu kampanju svoga čelnika, u kojemu ni članstvo, ni formalna stranačka tijela, ni formalni postupci kojima su uređeni odnosi u suvremenim demokratskim strankama nisu bili važni.

Prava priroda te organizacije najbolje je došla do izražaja u načinu odabira kandidata za parlamentarne izbore. Središnju ulogu u selekcijskom postupku imala je reklamna agencija Pubitalia. Prije parlamentarnih izbora 1994. njezinih 26 filijala diljem Italije dobilo je zadatak da pronađe prave kandidate za stranačke liste. Agencija je posegnula za datotekama svojih klijenata te je iz njih izdvojila oko dvije tisuće osoba s kojima su stručnjaci agencije vodili prethodne eliminacijske razgovore. U odabiru kandidata presudna su bila tri mjerila: nisu smjeli biti prestari, trebali su imati iskustva u privatnom poduzetništvu te nisu smjeli imati prethodna politička iskustva i veze sa starim strankama. Bilo je vrlo poželjno da budu televizični, a da bi se to utvrdilo, kandidati su morali korektno pročitati neki tekst i pokazati "dobru figuru" u televizijskom studiju. Selekcijski postupak prošlo je oko 400 kandidata, koji su se potom morali suočiti s još jednim, posljednjim, izazovom prije no što se nađu na kandidatskim listama: morali su sudjelovati u skupnom razgovoru i skupnoj večeri s Berlusconijem u njegovoj privatnoj vili. Nakon toga prošli su intenzivan 
DRUŠ. ISTRAŽ. ZAGREB GOD. 20 (2011) BR. 2 (112),

STR. 379-399

KASAPOVIĆ, M.: FORZA ITALIA... tečaj o ponašanju u izbornoj kampanji kojim se nastojalo umanjiti njihovo političko neiskustvo. Tako je i u selekciji kandidata za izbore Forza Italia prekinula veze sa stranačkom tradicijom zemlje.

U drugoj fazi od 1996. do 2001. vodstvo je postalo sklonije pretvaranju pokreta $\mathrm{u}$ stranku, a što je bilo uvjetovano porazom na parlamentarnim izborima 1996 . Vodstvo je spoznalo granice djelotvornosti stranke kao "izbornog odbora" koji vodi isključivo medijsku kampanju i okrenulo se izgradnji tradicionalnijih oblika organizacije i djelovanja. Počelo se govoriti o tome kako bi trebalo razviti "središnje i periferne strukture" koje bi pomogle u djelotvornijem širenju političkih zamisli, izboru vodstva i "organizaciji konsenzusa". Prihvaćen je novi statut 1997., koji je predviđao osnivanje stranačkih organizacija u regijama, provincijama i komunama. Potiče se porast članstva, među ostalim i za to da bi se popravilo financijsko stanje stranke. Stranka zadržava centralistički ustroj, ali uz neke poludemokratske pomake. Najvišim tijelom stranke postaje Nacionalni kongres, koji se prvi put sastao 1998. Premda je statutarno bilo predviđeno da se sastaje svake tri godine, drugi je skup održan tek 2004. Kongres su činile dvije skupine izaslanika. Prvu skupinu činili su izaslanici izabrani u skupštinama stranke u velikim gradovima i provincijama, pri čemu se cijenio broj glasova što ih je stranka dobila na zadnjim parlamentarnim izborima: svaka je gradska i provincijska organizacija slala po dva izaslanika plus po jednoga izaslanika na svakih pet tisuća glasova što ih je stranka osvojila u dotičnom gradu ili provinciji. I to je odstupalo od uvriježene prakse talijanskih stranaka, koje su broj izaslanika utvrđivale na temelju broja članova lokalnih stranačkih ogranaka ili organizacija. Drugu skupinu činili su dužnosnici stranke: zastupnici europskoga, nacionalnog i regionalnih parlamenata, članovi regionalnih vijeća, predsjednici frakcija u parlamentima i komunalnim vijećima, predsjednici i podpredsjednici provincija, gradonačelnici gradova s više od 15000 stanovnika, koordinatori stranke na gradskoj, provincijskoj i regionalnoj razini te ostali dužnosnici. Kongres nije bio tijelo u kojemu se demokratski odlučivalo, nego instancija na kojoj su aklamacijom potvrđeni predsjednik stranke i sve predložene odluke. Statut je predvidio i Nacionalno vijeće kao izvršno tijelo od 340 članova: Kongres je birao samo 50 članova, a ostali su bili dužnosnici stranke koji su uživali Berlusconijevo povjerenje. Predsjednički odbor činilo je šest članova, većinom visokih stranačkih dužnosnika i osoba koje je izravno imenovao Berlusconi. $\mathrm{U}$ toj se fazi ponešto promijenio i način odabira kandidata za izbore. Kandidate su predlagali regionalni koordinatori koje je imenovao Predsjednički odbor i koji su uživali Berlusconi- 
DRUŠ. ISTRAŽ. ZAGREB GOD. 20 (2011), BR. 2 (112)

STR. 379-399

KASAPOVIĆ, $M$. FORZA ITALIA..

\section{Ideološki profil}

jevo povjerenje. Više su uzimani u obzir političko iskustvo pojedinaca, nerijetko se hotimice posezalo za kadrovima starih stranaka, a počelo se voditi malo više računa i o njihovoj ukorijenjenosti u lokalne zajednice u kojima su se trebali natjecati za mandate.

Unatoč formalnim poludemokratskim pomacima, Berlusconi je nastavio vladati strankom poput monarha ili despota. Statut mu je dao ovlasti da vodi i predstavlja stranku, saziva sva stranačka tijela, imenuje visoke stranačke dužnosnike. Odlučivao je o svim važnijim pitanjima, određivao strategiju i taktiku stranke, gušio svaki pokušaj frakcijskoga djelovanja ili osobne neposlušnosti. Još je uvijek ustrajavao na tome da Forza Italia nikad neće biti masovna stranka staroga tipa, nego "prva velika postideološka stranka" u kojoj odlučuju birači i njihovi izabrani predstavnici, a ne birokrati, dužnosnici i profesionalni političari. Teško se odričući zamisli o pokretu, priznao je da se Forza Italia silom prilika pretvara u stranku, ali ostaje "živa snaga društva".

U trećoj fazi nakon pobjede na izborima 2001. zamisao o stranci opet odlazi u drugi plan. Oživljava koncept izbornog odbora, koji se treba pojaviti tri mjeseca prije izbora, a u međuvremenu stranka prestaje postojati, poput američkih stranaka. Promijenio se i postupak odabira kandidata. Vodstvo je odlučilo angažirati "lovce na glave" (head hunters), unoseći još jednu metodu ekonomskoga djelovanja u politiku. Kandidati su birani prema strukovnoj sposobnosti, vezanosti za lokalnu zajednicu, elokventnosti i potpunoj odanosti Berlusconiju. Tvrdi se da su odluke o kandidatima donesene za četrdeset minuta (Grasmück, 2005., 424), čime su u ropotarnicu povijesti bačeni tradicionalni postupci selekcije i napredovanja u stranci i politici, zasnovani na dugogodišnjoj ideološkoj privrženosti i političkoj aktivnosti pojedinaca.

Forza Italia nije bila zamišljena kao klasična ideološka stranka, nego se Berlusconijev osobni svjetonazor pretvorio u svojevrsnu pseudoideologiju cijele stranke. A on se temeljio na nekoliko vrijednosti: obitelji, poduzetništvu, natjecanju, napretku, učinkovitosti, slobodnom tržištu i solidarnosti, pri čemu se solidarnost razumijevala kao "kćerka pravednosti i slobode". Te su se vrijednosti "zgusnule" u ideološko preferiranje triju temeljnih institucija talijanskoga društva: obitelji, tržišta i Crkve. Na njima je izgrađen profil Forza Italia kao neoliberalne, pučke, katoličke, svjetovne i nacionalne stranke centra. ${ }^{6}$ Berlusconi je isticao svoj liberalni svjetonazor, svoju "strast prema slobodi" i vodio boj protiv "neliberalnih snaga", poglavito talijanske ljevice, kojoj spočitava da ne vjeruje u tržište, privatnu 
DRUŠ. ISTRAŽ. ZAGREB BR. 2 (112),

STR. 379-399

KASAPOVIĆ, M.: FORZA ITALIA.. GOD. 20 (2011)

inicijativu, profit i pojedinca. Analitičari su izračunali da je u svojim govorima najčešće rabio riječ "sloboda", koju je često suprotstavljao državi: "Mi želimo Italiju koja daje više mjesta privatnoj inicijativi, a manje državi. Mi želimo privatniju i manje državnu Italiju" (nav. u: Seißelberg, 1995., 224). Unatoč zazoru od ideologije, Forza Italia ideološki je bila najbliža novome desnom liberalizmu, koji se poglavito očitovao u nastojanju da se smanji uloga države u privredi i društvu (Hopkin i Paolucci, 1999., 325).

Talijansku ljevicu sustavno je proglašavao zakrinkanim komunistima koji lukavo prikrivaju svoje prave političke ciljeve. Uoči parlamentarnih izbora 1996., na kojima je pobijedio savez lijevoga centra Maslina, poručivao je biračima: "Ako Maslina pobijedi, više neće biti izbora". Htio je prestrašiti birače time da će nakon pobjede ljevica ukinuti demokraciju i zavesti komunističku diktaturu. Samoga je sebe nazivao osloboditeljem Italije od komunizma, "prvakom antikomunizma", kao da su do 1994. u Italiji na vlasti bili komunisti. Kako su svi znali da su sklapanjem conventio ad exludendum komunisti bili isključeni iz svih vlada nakon 1945., te su riječi budile opravdane sumnje u Berlusconijeve prave političke nakane. Ako je politički režim poslijeratne Italije bio komunistički, kakav je to režim kanio uspostaviti umjesto njega? Neće li se nakon pobjede na izborima odvažiti na promjenu cijeloga demokratskog političkog sustava, a ne samo dotadašnje politike? Berlusconi je doista pokušao promijeniti talijanski politički sustav, ali nije uspio u tome zato što su cijeli reformski paket građani odbacili na referendumu.

\section{PREZIDENCIJALIZACIJA IZVRŠNE VLASTI I FORZA ITALIA}

Prezidencijalizacija izvršne vlasti očituje se u porastu formalne i neformalne moći čelnika izvršne vlasti, što se najviše izražava u proširenju područja njihova samostalnog djelovanja. Šefovi izvršne vlasti sve su neovisniji o vladi i parlamentu, što se iskazuje povećanjem resursa kojima raspolažu, centralizacijom kontrole i koordinacije u oblikovanju javnih politika, primjenom strategije kontroliranoga "integralnog komuniciranja" kao sredstva definiranja alternativnih politika, poticanjem sve personaliziranijega glasovanja, pri čemu ured premijera ili predsjednika sustavno nadzire i ispituje njegovu osobnu popularnost i način na koji ga birači doživljavaju, ovlastima šefa izvršne vlasti da u vladu imenuje sve više nestranačkih tehnokrata i da brzo promovira političare koji nemaju uporišta u široj stranačkoj osnovici, češćim promjenama ministara u vladi, sve češćim pozivanjem šefa izvršne vlasti na "personalizirani mandat" koji ima u donošenju ključnih odlu- 
DRUŠ. ISTRAŽ. ZAGREB GOD. 20 (2011), BR. 2 (112)

STR. 379-399

KASAPOVIĆ, $M$ FORZA ITALIA.. davine označuju imenima premijera koji su ih obilježili: u Velikoj Britaniji govori se o tačerizmu i blerizmu, u Spanjolskoj o felipizmu, u Italiji o berluskonizmu itd. Donedavno su ti eponimi bili rezervirani samo za predsjedničke i polupredsjedničke sustave - primjerice, reganizam, degolizam, kekonizam, kučmanizam, jeljcinizam, putinizam, tuđmanizam te za diktature - lenjinizam, staljinizam, hitlerizam, frankizam, peronizam, titoizam.

U razdoblju "demokratske restauracije" nakon 1945. Italija je ustrojena kao čista parlamentarna republika u kojoj je imajući na umu katastrofalno naslijeđe dučeovskoga sustava iz doba fašizma - parlament konstitucionalno postavljen kao središnja politička institucija. Predsjednika republike birao je parlament i nije imao neograničene političke ovlasti. Premijer je postao primus inter pares $\mathrm{u}$ vladama koje su birane natpolovičnim većinama glasova u oba doma talijanskoga parlamenta. Stvorene su konstitucionalne pretpostavke za depersonalizaciju institucija predsjednika države i premijera. Talijanski su se političari izmjenjivali na predsjedničkim, premijerskim i ministarskim položajima, ne utiskujući ni jednome od njih osobni pečat i ne obilježavajući pojedina razdoblja talijanske politike vlastitim političkim zamislima i osobnim političkim stilovima. Calise (2005.) smatra Berlusconija prvim "monokratskim premijerom" u poslijeratnoj talijanskoj povijesti, koji je uz pomoć svoje monokratske stranke uspostavio monokratsku vladu. Kako je ona nastala?

Prva pretpostavka nastanka vlade koja dominira parlamentom bila je politička i egzistencijalna ovisnost zastupnika parlamentarne većine o vođi stranke. U parlamentarnoj frakciji stranke Forza Italia prevladavali su zaposlenici i poslovni partneri Berlusconijeva koncerna: najviše je bilo menadžera, poduzetnika, odvjetnika i slobodnih profesija, koji su činili gotovo 80 posto forcista u parlamentu (Seißelberg, 1995., 212; Grasmück, 2005., 428). Dokle god su bili svjesni da njihova politička i egzistencijalna budućnost ovisi o Berlusconiju, on je mogao računati na politički slabu frakciju koja će bespogovorno glasovati za zakone i politiku vlade u parlamentu.

Druga je pretpostavka bilo potpuno političko neiskustvo forcista: nakon izbora 1994. oko 91 posto zastupnika Forza Italia u Predstavničkom domu i oko 95 posto u Senatu sjelo je prvi put u parlamentarne klupe. Zastupnici parlamenta općenito su bili većinom politički neiskusni: oko 68 posto članova Predstavničkoga doma i oko 56 posto članova Senata prvi su put izabrani u parlament. Berlusconi je kasnije odustao od izopćenja pripadnika stare političke klase iz svoje stranke, pa se iskustvo zastupnika povećalo, ali se nije moglo mjeriti sa snalažljivosti i lukavosti stare političke kaste u parlamentu, koja 
DRUŠ. ISTRAŽ. ZAGREB GOD. 20 (2011) BR. 2 (112),

STR. 379-399

KASAPOVIĆ, M.: FORZA ITALIA... je od svršetka rata praktički držala talijanske vlade u šahu i poigravala se s njima kako je htjela.

Treću pretpostavku činila je uspostava premijerove kontrole nad svim ministrima i strankama u vladi. Ukinuo je tradicionalnu talijansku praksu prema kojoj su vođe drugih koalicijskih stranaka ostajale izvan vlade, te ih je uključio u vladu, učinio odgovornijima za njezin rad, ali i podvrgnuo osobnoj kontroli. Bio je, osim toga, sklon preuzimanju pojedinih resora ako je to smatrao svrsishodnim. Tako je nakon ostavke ministra vanjskih poslova Renata Ruggiera 2002. preuzeo njegovu dužnost te deset mjeseci formalno bio i ministar vanjskih poslova. ${ }^{7}$ Jednim od važnijih pokazatelja prezidencijalizacije smatra se i povećanje broja nestranačkih ministara, koji se osjećaju odanima ponajprije šefu vlade. U svoju treću vladu Berlusconi je, primjerice, uključio pet nestranačkih ministara i podministara, premda je u vladi bilo sedam stranaka koje su imale dovoljno kadrova da popune vladine resore. Osobni autoritarni stil ponašanja uspio je pretvoriti u neformalna pravila u političkim institucijama, koja su nerijetko važnija od formalnih.

Četvrtu pretpostavku činila je praksa vladanja. Tijekom Berlusconijeva premijerskog mandata vlada se pretvorila $u$ "sekundarnu normativnu vlast" (Calise, 2005., 92). Ponajprije, sustavno se povećavao broj prihvaćenih zakona koje je predložila vlada: u zakonodavnom razdoblju od 1987. do 1992., koje je trajalo 57,7 mjeseci, takvih je zakona bilo 65 posto; $\mathrm{u}$ mandatu od 1992. do 1994., koje je trajalo samo 23,7 mjeseci, udio se povećao na 74 posto; u mandatu od 1994. do 1996., koje je trajalo nepunih 25 mjeseci, udio je narastao na 88 posto, a od 1996. do 2001. pao je na 77 posto (Köppl, 2007., 133). Usporedno s time stalno se smanjivala zakonodavna inicijativa parlamenta. Vlada je tako povećala nadzor nad dnevnim redom parlamenta i praktički ga potpuno diktirala. Nadalje, stalno je povećavala broj uredaba (emergency bill) koje su stupale na snagu bez potpore parlamentarne većine, a mnoge od njih kasnije su se pretvorile u zakone. Ekspandirala je delegative legislative, to jest broj mjera koje je vlada donosila u okviru širokih smjernica što ih je utvrđivao parlament. Povećao se i broj private members bill, zakonskih inicijativa koje su potjecale od pojedinih zastupnika i čija se sudbina uglavnom rješavala u odborima. Parlament je oslabljen ukidanjem tajnoga glasovanja u velikom broju slučajeva. Ono je izvorno bilo motivirano željom da se smanje vanjski pritisci - pritisci talijanskih i europskih interesnih skupina i lobija - na zastupnike i poveća razvidnost odlučivanja u parlamentu. No pritisci se nisu smanjili, nego su se preusmjerili na odbore obaju domova, koji su preuzeli znatan dio zakonodavnoga posla. 
DRUŠ. ISTRAŽ. ZAGREB GOD. 20 (2011), BR. 2 (112)

STR. 379-399 FORZA ITALIA...
KASAPOVIĆ, $M$

Petu pretpostavku činili su stalni, djelomice uspješni, pokušaji da se izvršnoj vlasti podrede neovisni podsustavi političkoga sustava i dijelovi civilnoga društva. Berlusconi je kao premijer vodio vladu, kao vođa parlamentarne većine određivao je zakone, kao tajkun utjecao je na privredu, kao medijski mogul oblikovao je javno mišljenje. Jedino mu je izmicalo pravosuđe, pa je bio u stalnom ratu s njime. Usvajani su dekreti kojima se sprječavalo samostalno djelovanje pravosuđa. Oni nisu bili samo dokaz širenja ovlasti izvršne vlasti nad sudbenome, koja je načelno neovisna grana vlasti, nego su bili potaknuti osobnim interesima premijera i onemogućavali su dekriminalizaciju talijanske politike i društva.

Naposljetku, u mandatu Berlusconijeve vlade bilo je i formalnih pokušaja da se ozakone izravni izbori premijera te tako i strukturno prezidencijalizira parlamentarni sustav, kao u Izraelu (Kasapović, 2008.). U siječnju 2004. Odbor za ustavne poslove Senata odobrio je prijedlog temeljite ustavne reforme, koja je uključivala i izravne izbore premijera. Prema tom prijedlogu, dotadašnji predsjednik Vijeća ministara preimenovao bi se u premijera. Predsjednik republike izgubio bi ovlast da imenuje mandatara za sastav vlade, pa bi to automatski postao vođa pobjedničke stranke. Premijer bi imenovao i opozivao ministre. Vlada više ne bi mogla biti podvrgnuta glasovanju o povjerenju u parlamentu, nego bi Camera dei deputati - prvi dom parlamenta, koji je formalno i stvarno trebao postati glavni dom, čime bi bilo završeno razdoblje genuinoga bikameralizma - izrazila svoje mišljenje o vladi glasovanjem pošto bi premijer izložio zastupnicima program vlade. Premijer bi mogao raspustiti parlament (Köppl, 2007.; Bull i Newell, 2009.). Prijedlog ustavne reforme nije prošao na referendumu, jer je protiv njega glasovalo 61,7 posto građana. Premda nije uspio formalno uspostaviti premijerski parlamentarizam, Berlusconi je ipak zamijenio tradicionalnu sliku talijanskoga premijera kao posrednika u vladi slikom autoritarnoga i autoritativnoga premijera.

\section{ZAKLJUČNO RAZMATRANJE}

Forza Italia tipološki se može svrstati u kartelske stranke: nastala je kao proizvod privrednog kartela, osnovali su je i vodili menadžeri toga kartela, organizirana je prema uzoru na kartel, djelovala je po načelima političkoga tržišta, smisao svoga postojanja procjenjivala je isključivo prema uspjehu u prodaji svojih usluga na političkom tržištu, dakle prema broju osvojenih glasova i mandata. Imala je, međutim, dvije osobitosti u odnosu na ostale kartelske stranke. Bila je, prvo, krajnji oblik kartelske stranke, koji je gotovo sva pravila kartel- 
DRUŠ. ISTRAŽ. ZAGREB GOD. 20 (2011) BR. 2 (112),

STR. 379-399

KASAPOVIĆ, $M$ : FORZA ITALIA... je, drugo, posebna po tome što nije proizašla iz nekoga kartela - recimo, iz mljekarskoga, rudarskoga ili naftnoga koncerna - nego iz medijskoga koncerna koji je cijelu stranku profilirao, "zapakirao" i prodavao kao uspješan medijski proizvod. Stranka se munjevito razvila i nametnula javnosti zahvaljujući uporabi agresivnih marketinških metoda medijskoga koncerna iz kojega je iznikla. Taj je medijski kartel uspješno iskoristio uznapredovali prijelaz iz stranačke u medijsku logiku političke borbe te ga je dodatno poticao i nametao. On je u Italiji više nego u ijednoj drugoj europskoj državi uspio, makar privremeno, reprezentativnu demokraciju zamijeniti "prezentativnom demokracijom" (Pallaver, 1997., 418). Stranku Forza Italia kartelskom čini i visok stupanj profesionalizacije i specijalizacije vodstva u upravljanju strankom, velika distancija između vodstva i malobrojnoga, neutjecajnoga članstva te kapitalno intenzivna izborna kampanja. U Italiji se, međutim, pokazalo da model stranke ustrojene i vođene poput poslovne tvrtke nije stabilan i da tendencijski potkopava institucionalizaciju stranaka i stranačkih sustava zato što ne posjeduje ni jedan izvor stabilnosti tradicionalnih masovnih stranaka: ni institucionalnu solidnost unutarnjih struktura, ni brojno stranačko članstvo i biračko tijelo, ni koherentnu socijalnu osnovicu, ni službenu ideologiju na koju bi se oslanjale javne politike vlade. "Zapravo, politike i programi pod snažnim su utjecajem rezultata ispitivanja javnoga mišljenja i političkog 'istraživanja tržišta"' (Hopkin i Paolucci, 1999., 334).

Forza Italia je, nadalje, i tipična predsjednička stranka koja je nastala u sklopu prezidencijalizacije talijanske politike. Zahvaljujući financijskoj moći, prirodi medijskoga carstva, prihvaćenim obrascima političkoga djelovanja u stranci i izvan nje, ali i osobnom političkom i drugom umijeću svoga osnivača i vođe, ona je bila personalističkija od drugih prezidencijalističkih stranaka ne samo u parlamentarnim sustavima (primjerice, od Blairovih laburista), nego i u polupredsjedničkim sustavima, primjerice, od Mitterandovih socijalista.

Nastanak i munjevit uspon Forza Italia nije shvatljiv bez povijesno-političkoga i socijalno-kulturnoga konteksta u Italiji potkraj 1980-ih i na početku 1990-ih godina. Riječ je o temeljitoj krizi talijanskoga političkog sustava, koja se dramatično očitovala u urušavanju cijeloga stranačkog sustava i raspadu Demokršćanske i Komunističke stranke kao dviju njegovih stožernih poslijeratnih stranaka. Tako je nastao prazan prostor koji su brzo i lako mogle zauzeti nove političke snage, kojima je praktički bio otvoren put do vlasti. ${ }^{8}$ Birači, koji su se našli odsječeni od svojih tradicionalnih veza s demokršćanima i komunistima, izbačeni iz svojih starih katoličkih i sekularnih potkulturnih utvrda, tražili su novu "političku domovinu". Većina birača bivše desnice našla ju je u Forza Italia. 
DRUŠ. ISTRAŽ. ZAGREB GOD. 20 (2011), BR. 2 (112)

STR. 379-399

KASAPOVIĆ, $M$ FORZA ITALIA..
Izborni podaci pokazuju da su se njezine biračke utvrde umnogome poklapale s nekadašnjim utvrdama demokršćana, ali i socijalista, dakle stranaka "stare većine". Zanimljivo je da ni naziv Forza Italia nije bio originalan, jer su ga demokršćani rabili kao svoj izborni slogan u kampanji 1987. (Bardi, 1996., 357, 358; Shin i Agnew, 2007.). No to ne bi bilo dostatno za uspjeh. U Forza Itala obavljene su ideološke, političke i organizacijske predradnje koje su joj omogućile da duboko posegne i za drugim dijelovima biračkoga tijela. Hotimično preusmjeravanje sa stranačke, programske i kandidatski orijentirane izborne kampanje na kampanju usmjerenu poglavito na jednoga političkog vođu privuklo je vrlo raznoliko biračko tijelo koje glasovanjem za Berlusconija nije osjećalo da izdaje svoje stare ideološke vrijednosti i odustaje od starih političkih lojalnosti. Osim birača bivših demokršćana, već u izborima 1994. Berlusconi je uspio pridobiti bivše birače republikanaca i socijalista, ali i sjevernih autonomaša, novofašista, zelenih i pripadnika raznih prosvjednih pokreta. Birači forcista novačili su se među svim socijalnim slojevima i skupinama. Na početku su prevladavali poduzetnici i kućanice koje su po cijele dane gledale Berlusconijeve televizijske kanale, a kasnije je bilo sve više umirovljenika, radnika, napose uposlenih u privatnom privrednom sektoru i nezaposlenih. Među biračima forcista izrazito su bili zastupljeni sitni poduzetnici, nezaposlene žene, uvjereni katolici, mladi Talijani u potrazi za poslom te skupine s nižim i srednjim obrazovanjem. Najveći otpor prema njegovoj politici pokazali su studenti, intelektualci i neke skupine javnih službenika i namještenika, poput nastavnika (Fabbrini i Gilbert, 2001., 526). Natprosječno uspješan bio je u privlačenju birača razvijenih sjevernih regija, ponajprije Lombardije, ali i nerazvijenih južnih regija, poput Sicilije. Izvan njegove prevlasti ostao je samo tradicionalni "crveni pojas" što ga čine tri regije srednje Italije - Toskana, Umbrija i Emilia-Rogmana. Po opsegu i dubini zahvaćanja u vrlo različite segmente biračkoga tijela Forza Italia ispunila je snove ideologa i tvoraca stranaka koje grabe sve.

Drugi razlog uspjeha treba tražiti u Berlusconijevoj političkoj strategiji. On je praktički ignorirao ideološki, politički i mentalitetni jaz između sustavskih i protusustavskih stranaka u Italiji te je ušao u otvoreni izborni i politički savez s dvjema protusustavskim strankama, koje su uz to bile međusobno dijametralno oprečne. Godine 1994. sklopio je izborni savez s autonomaškom i separatističkom Sjevernom ligom, ali i s državnointegralističkim, novofašističkim Talijanskim društvenim pokretom. Tako je regionalne secesioniste sa Sjevera i integralističke nacionaliste s Juga integrirao najprije u prosustavski izborni kartel, a potom i u politički sustav. Pokretaše je prisilio da se odreknu fašističkoga naslijeđa i pomaknu prema 
DRUŠ. ISTRAŽ. ZAGREB GOD. 20 (2011) BR. 2 (112),

STR. 379-399

KASAPOVIĆ, $M$ : FORZA ITALIA.. centru, pa je taj proces transformacije formalno označen prijelazom u postfašističku Nacionalnu alijansu 1995. Ligaše je prinudio da prihvate koncept devolucije, to jest federalizacije Italije. Prema pripravnosti da sklopi izborne i političke saveze s protusustavskim strankama te sposobnosti da ih integrira u politički sustav razlikovao se od vođa velike većine konzervativnih stranaka u drugim europskim zemljama.

Prema spomenutima, ali i mnogim drugim obilježjima, stvoren je fenomen berluskonizma kao "jednog stila politike" i "osebujne političke prakse", što u sebi sažimlju niz "normalnih", ali i patogenih, političkih elemenata (Köppl, 2006.; Grubiša, 2007., 7. i d.). Forza Italia ne može se razumjeti izvan općega trenda kartelizacije i prezidencijalizacije politike u europskim demokracijama. Ono što je u njoj bilo posebno i osebujno treba, pak, pripisati kontekstualnim uvjetima u kojima je nastala i djelovala, ponajprije talijanskom političkom sustavu i političkoj kulturi.

\section{BILJEŠKE}

1 U političkoj znanosti prijelaz iz jedne republike u drugu konvencionalno se vezuje uz promjenu ustava. U Italiji se stoga ne može govoriti o prijelazu u Drugu Republiku, jer nije promijenjen ustav i nisu temeljito reformirane stare i konsolidirane nove političke institucije. Raspravu o tome v. u: Pasquino (1994.), Weber (1995.), Morlino i Tarchi (1996.), Recchi (1996.), Zohlnhöfer (1998., 2002.), Fabbrini (2000.), Fabbrini i Gilbert (2000., 2001.), Donovan (2003.), Bull (2004.), Calise (2005.), Köppl (2007.), Bellucci (2008.).

2 Model kartelske stranke izvorno su izložili Katz i Mair (1995., 1996.), a njihove su argumente, više ili manje uspješno, podržavali i osporavali Koole (1996.), Kitschelt (2000.), Lucardie (2000.), Helms (2001.), Beyme (2002.), Diamond i Gunther (2001.), Gunther i sur. (2002.), Gunther i Diamond (2003.) i drugi. O sličnu modelu profesionalne biračke stranke v. Panebianco (1988.).

3 Berlusconijeva biografija odgovara predodžbi o amerikaniziranom prototipu selfmademana. Biografi bilježe da je "poduzetničke" sklonosti pokazivao još u ranoj dobi kad je školskim drugovima pisao domaće zadaće za novac - a novac nije vraćao i kad bi za napisane zadaće dobili lošu ocjenu - i organizirao kućne "kazališne predstave" za koje je roditeljima, susjedima i prijateljima naplaćivao ulaznice. U odraslijoj dobi bio je prodavač usisavača, svadbeni fotograf, animator zabave na brodskim kružnim putovanjima, basist i pjevač u barovima koji je najviše volio izvoditi pjesme Yvesa Montanda i Franka Sinatre. Nakon diplomiranja na pravnom fakultetu otisnuo se u poduzetničke vode u građevinarstvu. Zbog uspjeha u poduzetništvu predsjednik Italije dodijelio mu je 1977. počasni naslov Cavaliere del lavoro (Vitez rada). Otada se Berlusconi u medijima, najčešće posprdno, naziva cavaliere. Potkraj 1970-ih okreće se televiziji te se ubrzo pretvara u najvećega medijskog tajkuna u suvremenoj Italiji. Cijela njegova poslovna karijera bila je praćena sumnjama u podrijetlo novca te aferama s dugovima, porezima, pranjem novca, podmićivanjima i sl. (Grasmück, 2005., 73-90). 
DRUŠ. ISTRAŽ. ZAGREB GOD. 20 (2011), BR. 2 (112)

STR. 379-399

KASAPOVIĆ, $M$ FORZA ITALIA..
${ }^{4}$ Na pitanje birača tko je Berlusconi, trebalo je odgovarati ovako: "1. Izgradio je gradove od nule. 2. NK Milan izveo je iz druge lige i doveo ga na prvo mjesto u Italiji, Europi i svijetu. 3. Izazvao je svemoćni javni monopol, RAI, koji je bio oslonac svih stranaka, i pobijedio ga. 4. Osnovao je novu stranku i pretvorio je u prvu stranku u Italiji. 5. Sada želi našu zemlju, koja je gotovo zadnja u Europi, dovesti na vrh. 6. Zašto mu ne bismo dopustili da to pokuša? Koje nam se druge mogućnosti otvaraju?" Ljevica je, naprotiv, samo: 1 . gladna vlasti; 2 . gladna položaja; 3. gladna novca. Komunizam na vlasti izazvao je samo: 1. bijedu, 2. teror, 3. smrt. S komunizmom na vlasti protivnici su: 1 . u egzilu, 2. u zatvoru, 3. na groblju" (nav. u: Grasmück, 2005., 250).

5 Bardi (1996., 346) navodi da su tri glavne članice pobjedničke koalicije 1994. - Forza Italia, Sjeverna liga i Nacionalna alijansa - prednjačile u poticanju protustranačkih osjećaja te da njihov izborni uspjeh treba tumačiti kao "trijumf protustranačkoga sentimenta na masovnoj razini". U parlamentarnim izborima 1994. samo su se tri važna izborna aktera nazivala strankama - Stranka demokratske ljevice, Socijalistička stranka Italije i Pučka stranka Italije. Protustranački osjećaji samo su jedan od izraza talijanske političke kulture, koju obilježuju zasićenost građana politikom i zazor od nje, a paradigmatski su izraženi u popularnoj izreci "Piove, governo ladro!", to jest: "Pada kiša, lopovska vlado!"

${ }^{6} \mathrm{Na}$ prvome stranačkom kongresu 1998. Berlusconi je rekao da je Forza Italia "stranka sredine, centar političkoga sustava Italije. Ona je liberalna, ali ne elitistička stranka nego, štoviše, liberalnodemokratska pučka stranka; ona je katolička, ali ne konfesionalna stranka; ona je svjetovna, ali ne netolerantna i laicistička stranka; ona je nacionalna, ali ne centralistička stranka. Ona... bi se posve jednostavno mogla nazvati... strankom ljudi" (nav. u: Grasmück, 2005., 216).

7 Nakon što je Ruggiero upozorio na euroskepticizam u talijanskoj vladi, Berlusconi je rekao: "Ruggiero je tehnički ministar i u tom svojstvu ja sam ga pozvao u vladu: ne postoji nikakva mogućnost da ono što on kaže ima političke posljedice. I to stoga što ja vodim talijansku vanjsku politiku" (nav. u: Grubiša, 2007., 139).

8 Raspad staroga stranačkog sustava, napose Demokršćanske i Socijalističke stranke, osobno je ugrozio Berlusconija i njegovo poslovno carstvo. Izgubivši dugogodišnje zaštitnike među demokršćanima i socijalistima, Berlusconi je shvatio da se odsad mora štititi sam, i to tako da uđe u politiku i osvoji vlast (Hopkin i Paolucci, 1999., 321; Köppl, 2006., 439).

\section{LITERATURA}

Ansell, C. K. i Fish, S. M. (1999.), The Art of Being Indispensable: Noncharismatic Personalism in Contemporary Political Parties. Comparative Political Studies, 32 (3): 283-312. doi:10.1177/0010414099 032003001

Bardi, L. (1996.), Anti-Party Sentiment and Party System Change in Italy. European Journal of Political Research, 29 (3): 345-363. doi:10. 1111/j.1475-6765.1996.tb00656.x

Bellucci, P. (2008.), Why Berlusconi's Landslide Return? A Comment on the 2008 Italian General Election. Politische Vierteljahresschrift, 49 (4): 605-617. doi:10.1007/s11615-008-0115-0 
DRUŠ. ISTRAŽ. ZAGREB GOD. 20 (2011) BR. 2 (112),

STR. 379-399

KASAPOVIĆ, M. FORZA ITALIA..
Beyme, K. v. (2002.), Transformacija političkih stranaka, Zagreb: Fakultet političkih znanosti.

Bull, M. J. (2004.), Parliamentary Democracy in Italy. Parliamentary Affairs, 57 (3): 550-567. doi:10.1093/pa/gsh044

Bull, M. J. i Newell, J. L. (2009.), Still the Anomalous Democracy? Politics and Institutions in Italy. Government and Opposition, 44 (1): 42-67. doi:10.1111/j.1477-7053.2008.01275.x

Calise, M. (2005.), Presidentialization, Italian Style. U: T. Poguntke i P. Webb (ur.), The Presidentialization of Politics (str. 88-106), Oxford: Oxford University Press.

Diamond, L. i Gunther, R. (ur.) (2001.), Political Parties and Democracy, Baltimore i London: Johns Hopkins University Press.

Donovan, M. (2003.), A Second Republic for Italy? Political Studies Review, 1 (1): 18-33. doi:10.1111/1478-9299.00003

Fabbrini, S. (2000.), Political Change without Institutional Transformation: What Can We Learn from the Italian Crisis of the 1990s? International Political Science Review, 21 (2): 173-196. doi:10.1177/01925 12100212004

Fabbrini, S. i Gilbert, M. (2000.), When Cartels Fail: The Role of the Political Class in the Italian Democratic Transition. Government and Opposition, 35 (1): 27-48. doi:10.1111/1477-7053.00010

Fabbrini, S. i Gilbert, M. (2001.), The Italian General Elections of 13 May 2001: Democratic Alternation or False Step. Government and Opposition, 36 (4): 519-536. doi:10.1111/1477-7053.00079

Furlong, P. (2006.), Institutional Fragmentation in Parliamentary Control: The Italian Case. U: N. D. J. Baldwin (ur.), Executive Leadership and Legislative Assemblies (str. 174-192), London i New York: Routledge.

Grasmück, D. (2005.), Die Forza Italia Silvio Berlusconis, Frankfurt na Majni: Peter Lang.

Grubiša, D. (2007.), Berluskonizam, Rijeka: Novi list i Adamić.

Gunther, R., Montero, J. R. i Linz, J. J. (ur.) (2002.), Political Parties. Old Concepts and New Challenges, Oxford: Oxford University Press.

Gunther, R. i Diamond, L. (2003.), Species of Political Parties. A New Typology. Party Politics, 9 (2): 167-199. doi:10.1177/13540688030092003

Helms, L. (2001.), "Die Kartellparteien" - These und ihre Kritiker. Politische Vierteljahresschrift, 42 (4): 698-708. doi:10.1007/s11615-0010104-z

Hopkin, J. i Paolucci, C. (1999.), The Business Firm Model of Party Organization: Cases from Spain and Italy. European Journal of Political Research, 35 (3): 307-339. doi:10.1111/1475-6765.00451

Hornig, E. C. (2007.), Forza Italia zwischen Volks- und Kartell-Partei. Zeitschrift für Parlamentsfragen, 38 (4): 798-815.

Kasapović, M. (2004.), Personalizacija izbora: mit ili stvarnost? Društvena istraživanja, 13 (3): 363-381.

Kasapović, M. (2008.), Izravni izbori premijera: slom izraelskog eksperimenta. Društvena istraživanja, 17 (6): 1071-1087. 
DRUŠ. ISTRAŽ. ZAGREB GOD. 20 (2011), BR. 2 (112) STR. 379-399

KASAPOVIĆ, $M$ FORZA ITALIA..
Katz, R. S. i Mair, P. (1995.), Changing Models of Party Organization and Party Democracy. The Emergence of Cartel Party. Party Politics, 1 (1): 5-28. doi:10.1177/1354068895001001001

Katz, R. S. i Mair, P. (1996.), Cadre, Catch-all or Cartel? A Rejoinder. Party Politics, 2 (4): 525-534. doi:10.1177/1354068896002004005

Kitschelt, H. (2000.), Citizens, Politicians, and Party Cartellization: Political Representation And State Failure In Post-Industrial Democracies. European Journal of Political Research, 37 (2): 149-179. doi:10. 1111/1475-6765.00508

Koole, R. (1996.), Cadre, Catch-all or Cartel? A Comment to the Notion of the Cartel Party. Party Politics, 2 (4): 507-523. doi:10.1177/ 1354068896002004004

Köppl, S. (2006.), Italien unter Berlusconi - eine Demokratie in Gefahr. Zeitschrift für Politik, 53 (4): 438-453.

Köppl, S. (2007.), Das politische System Italiens, Wiesbaden: VS Verlag für Sozialwissenschaften.

Lucardie, P. (2000.), Prophets, Purifiers and Prolocutors. Towards a Theory on the Emergence of New Parties. Party Politics, 6 (2): 175-185. doi:10.1177/1354068800006002003

Morlino, L. (1996.), Crisis of Parties and Change of Party System in Italy. Party Politics, 2 (1): 5-30. doi:10.1177/1354068896002001001

Morlino, L. i Tarchi, M. (1996.), The Dissatisfied Society: The Roots of Political Change in Italy. European Journal of Political Research, 30 (1): 41-63. doi:10.1111/j.1475-6765.1996.tb00667.x

Pallaver, G. (1997.), Der Winterkönig. Berlusconis Versuch, Leadership auszuüben und der repräsentativen Demokratie eine plebiszitäre Krone aufzusetzen. Österreichische Zeitschrift für Politikwissenschaft, 26 (4): 407-422.

Panebianco, A. (1988.), Political Parties: Organization and Power, Cambridge: Cambridge University Press.

Pasquino, G. (1994.), The Birth of the "Second Republic". Journal of Democracy, 5 (3): 107-113.

Poguntke, Th. i Webb, P. (ur.) (2005.), The Presidentialization of Politics. A Comparative Study of Modern Democracies, Oxford: Oxford University Press. doi:10.1093/0199252017.003.0015

Recchi, E. (1996.), Fishing from the Same Schools: Parliamentary Recruitment and Consocciationalism in the First and Second Italian Republic. West European Politics, 19 (2): 340-359. doi:10.1080/014023 89608425137

Samuels, D. J. (2002.), Presidentialized Parties: The Separation of Powers and Party Organization and Behavior. Comparative Political Studies, 35 (4): 461-483. doi:10.1177/0010414002035004004

Seißelberg, J. (1995.), Berlusconis Forza Italia. Wahlerfolg einer Persönlichkeitspartei. U: W. Steffani i U. Thaysen (ur.), Demokratie in Europa: Zur Rolle der Parlamente (str. 203-231), Opladen: Westdeutscher Verlag.

Shin, M. E. i Agnew, J. (2007.), The Geographical Dynamics of Italian Electoral Change, 1987-2001. Electoral Studies, 26 (2): 287-302. doi:10. 1016/j.electstud.2006.05.002 
DRUŠ. ISTRAŽ. ZAGREB GOD. 20 (2011) BR. 2 (1 112$)$

STR. 379-399

KASAPOVIĆ, M.: FORZA ITALIA..
Weber, P. (1995.), Italiens demokratische Erneuerung. Anpassungsprobleme einer "schwierigen" Demokratie (1989-1994). U: W. Steffani i U. Thaysen (ur.), Demokratie in Europa: Zur Rolle der Parlamente (str. 178-204), Opladen: Westdeutscher Verlag.

Zohlnhöfer, R. (1998.), Die Transformation der italienischen Parteiensystems in den 90er Jahren. Zeitschrift für Politikwissenschaft, 8 (4): 1371-1396.

\section{Forza Italia: An Italian Story}

Mirjana KASAPOVIĆ

Faculty of Political Science, Zagreb

Since it emerged in the political life of Italy at the beginning of the 1990s Forza Italia has caused many concerns and controversies among analysts of Italian politics and scholars of political parties. What kind of a political phenomenon is it? Was it a party, a cartel, personalistic or presidential type of modern European political party? Or was it another Italian anomaly that cannot be theoretically generalized and categorized? It turned out that Forza Italia was the Italian expression of general cartelization and presidentialization of contemporary politics which affected three major political arenas: elections, political parties and executive power. The article discusses how it was created, its organizational structure, ideological profile and patterns of political action in these three arenas. The conclusion is that the momentary political rise of Forza Italia was decisively influenced by several contextual factors. These factors are, first, the complete collapse of the old Italian political parties and party system; it has prompted voters to abandon their traditional Catholic and secular political blocs. Second, the origin of the party from media empire; it has enabled Forza Italia to fully colonize politics through the media. Third, Silvio Berlusconi's tendency to enter into political alliances with anti-systematic parties. Fourth, his personal political style which has turned into informal rules of action in political institutions. And fifth, his willingness to use criminogenous methods of action.

Keywords: Forza Italia, presidentialization of politics, presidential party, cartel party, Berlusconism

\section{Forza Italia: Eine italienische Geschichte}

Mirjana KASAPOVIĆ

Fakultät der politischen Wissenschaften, Zagreb

Seit ihrem Erscheinen Anfang der 90er-Jahre des 20. Jahrhunderts sorgte Forza Italia für vielfältige Unklarheiten und Meinungsunterschiede unter Politologen und 
DRUŠ. ISTRAŽ. ZAGREB GOD. 20 (2011), BR. $2(112)$

STR. 379-399

KASAPOVIĆ, $M$. FORZA ITALIA..
Beobachtern der italienischen Politik. Worin bestand dieses politische Phänomen? Betrachtet man Forza Italia als Partei, stellt sich die Frage, ob sie zum kartellhaften, personalistischen oder präsidentialistischen Typ der modernen europäischen Partei gehörte. Oder handelte es sich etwa um eine unter vielen "italienischen Anomalien", die in theoretischer Hinsicht nicht verallgemeinert und kategorisiert werden kann? Wie es sich zeigte, war Forza Italia eine italienische Erscheinungsform der allgemeinen Kartellisierung und Präsidentialisierung in der modernen Politik, die in drei großen Bereichen des politischen Lebens um sich griff: im Wahlkampf, in den politischen Parteien und in der Exekutive. Der vorliegende Text untersucht Entstehungsgeschichte und Organisation von Forza Italia, ferner ihr ideologisches Profil und die Formen ihrer politischen Tätigkeit in den genannten Bereichen des politischen Lebens. Die Verfasserin kommt zum Schluss, dass der schlagartige Erfolg von Forza Italia dem maßgeblichen Einfluss mehrerer gleichzeitig auftretender Faktoren zu verdanken ist. Dazu gehören: der völlige Verfall der alten italienischen Parteien und des einstigen Parteiensystems, der die Wähler veranlasste, ihre traditionellen katholischen und säkularen Lager aufzugeben; die Entstehung der Partei aus einem Medienkonzern, was eine völlige mediale Kolonialisierung der Politik zur Folge hatte; der Umstand, dass Berlusconi nicht zurückschreckte vor politischen Bündnissen mit Partnern, die mit den Systemparteien verfeindet waren; Berlusconis persönlicher politischer Stil, der sich in unformellen politischen Vorgehensweisen niederschlug; schließlich die Inanspruchnahme kriminogener Vorgehensweisen.

Schlüsselbegriffe: Forza Italia, Präsidentialisierung der Politik, Präsidentenpartei, Kartellpartei, Berlusconismus 